independence from foreign interests.

"Apart from opening the minds of many people to the problem of relating science to technical needs, and providing funds for training, I don't think CONICIT has been able to do much more in achieving its original goals," says Dr Carbonell of, IVIC who points out that $95 \%$ of patents taken out in Venezuela are still foreign, and that of the remaining nationally-owned patents, hardly any have been exploited.

CONICIT's problems are reflected at IVIC itself. One of the effects of the marginalisation of science is, it is claimed, a lack of respect for basic science as a profession; salaries are considerably lower than in universities, where teaching loads are so heavy that relatively little research is carried out.

In recent years IVIC has, for both ideological and financial reasons, been attempting to shift its focus away from a primary concern for basic science to embrace more applied subjects as well. The institute now has a small but active programme in solar energy research, concentrating in particular on methods of growing cadmium crystals, and is planning an investigation into techniques for the gasification of coal.

The institute also has a small research reactor, used not only for train- ing engineers in handling nuclear materials but also for producing isotopes for medical and industrial use. At present, Venezuela has no plans for a nuclear energy programme; "but we are training people to make the right decisions, when these become necessary," says Dr Carbonell.

So far, however, as with CONICIT, industry's response to IVIC's efforts in the field of applied science has been disappointing. "Although lip service is given to the need to develop applied research, there does not really seem to be much real demand for it," according to Dr Marcel Roche, IVIC's first director and now editor of the Latin American journal Interciencia.

"Venezuelan industry tends to go for the maximum benefits with the lowest risks. The result is that research remains peripheral to the interests of industry; and this is a situation which has not been changed by CONICIT."

One attempt to improve things has been the drafting of a new law, similar to that which was introduced in Peru in 1971 (see below), which would oblige all industrial enterprises, to contribute a proportion of their gross profits to a research and development fund administered by CONICIT.

"In the future, it is essential that

research receives financial backing from the industrial sector. Not only will this provide research institutions with more resources, but it will also help protect industry from foreign interests," says Dr Obregon.

If the proposed law is accepted by the Venezuelan Congress-and this will depend largely on the outcome of the forthcoming presidential elections, as well as new Parliamentary elections next year-the result will be to put CONICIT in a much stronger position not merely to plan, but also to carry out a coordinated research strategy. It could also increase its budget, currently less than $\$ 2 \mathrm{~m}$ a year, by a factor of up to ten.

And what about the future of basic science? Dr Roche, a firm supporter of the need for developing countries to build a basic research capability to encourage technological independence, is optimistic.

"In my lifetime I have had the opportunity to see Venezuelan science grow at a relatively impressive rate. When I began to do research, there were in the country only six or seven professional investigators; now there are hundreds, well prepared and competent."

\title{
Peru rings the changes in science policy
}

PERu has become the setting for a fierce debate on the respective roles that scientists and government planners should play in the design and administration of a national science policy. The focus of the debate is a proposal now before Peru's military leaders to upgrade the country's National Research Council, at present a primarily advisory body made up of eminent scientists, and to use it as the basis for establishing a "national system for science and technology".

The proposal is being resisted by groups such as the Institute for the Research in Industrial Technology (ITINTEC), which claim that a strongly centralised research policy would restrict the advantages of flexibility gained from the present system of relatively autonomous research institutes, each linked to separate government departments.

Others, including members of Peru's National Planning Institute-a government agency whose director has ministerial status-while agreeing on the need for a central programme for science and technology, argue that it should be conceived within, rather than parallel to. the existing social and economic planning machinery.

The root of the current conflict can be traced back to an ambiguity that has existed since Peru's military government came to power in 1968 . Keen to restrict the power of foreign interests and promote the country's technological independence, the government has encouraged the growth of a network of sectoral research institutes. There are now about 230 separate research institutes in Peru, half in the private and half in the public sector. And many, such as the Instituto del Mar del Peru (IMARPE) in Callao, enjoy an international reputation. At the same time, however, the government created as one of its first post-revolutionary acts the National Research Council, which theoretically has responsibility for establishing a national science and research policy.

"The problem is that when the government set up the council, it did not provide it with the authority or the resources to carry out the responsibilities it had been given," according to the council's current president, Dr Antonia Pinilla. "In consequence, the council has not been able to nlay the leadership role that it should have done."

As a remedy, Dr Pinilla, a previous Minister of Labour and a co-founder of the private University of Lima, has proposed a "national svstem" for coordinating the country's research efforts. (Such a system has already been promised by the government in its Tupac Amaru Plan for returning to civilian rule by 1980).

The system would have two main components. The first would be a $\mathrm{Na}$ tional Council for Science and Technology, a "normative body" responsible for setting policy goals and research priorities. The council would be made up of eminent scientists and those responsible for the various scientific and technological research institutes. The second would be an administrative body known as the National Institute for Science and Technology. In addition to carrying out the policies determined by the council, the institute would be responsible for setting up both an Advanced Centre for Science and Technology-a type of "Peruvian MIT", as Dr Pinilla describes it, concerned with postgraduate studies and research-and a national Centre for Scientific and Technological Documentation.

Dr Pinilla has suggested that the head of the national system act as both president of the council and as director of the institute, and that in recognition of the central role of science and technology in the country's economy, he or she be given equivalent ministerial status to the director of the 
National Planning Institute.

The proposed science policy machinery has received enthusiastic support from amongst others, the science policy secretariat of the United Nations Educational, Scientific and Cultural Organisation (UNESCO), which has been promoting the "minister of science" approach for a number of years.

Others inside the country, however, are less enthusiastic. Despite $\mathrm{Dr}$ Pinilla's promise that the system will "respect the academic autonomy" of individual research institutions, they are worried that attempts will be made to impose unrealistic goals and objectives while limiting flexibility.

Particularly concerned are members of ITINTEC, an agency set up by the government in 1971 to stimulate research in the various areas of productive industry. At present, although working to support areas that have been given priority by the government, ITINTEC is able to operate relatively independently because its main income comes directly from industry.

Under the law establishing ITINTEC, all companies in Peru have to set aside $2 \%$ of their gross profits each year for research. A company can either submit for ITINTEC's approval a research project which it wishes to carry out itself, or hand the money over directly to ITINTEC, which will use it to finance its own research.

The model seems to have worked quite well, and the Venezuelan government is contemplating introducing a similar system (see above). Over a third of ITINTEC's research projects are carried out by universities, and the institute has established centres for wood technology and non-metallic materials, as well as what is claimed to be the best technical information service in Peru.

Furthermore ITINTEC has recently received a $\$ 2$ million grant from the US Agency for International Development to investigate the application of "appropriate technology" ideas to Peru -a project which will include studying the possibility of restoring the famous agricultural terraces built by the Incas, now realised to be a highly efficient means of using soil and rain-fall in mountain areas.

Under the proposed new system. although ITINTEC and other research institutes would remain responsible for developing and carrying out their own research programmes, they would be required to present plans and budgets to the National Council for prior approval. "We feel strongly that technological research and development should be carried out within each sector of industry. without heing subiect to any strong centralised control. which we have been luckv ennugh to avoid in the past." according to Dr

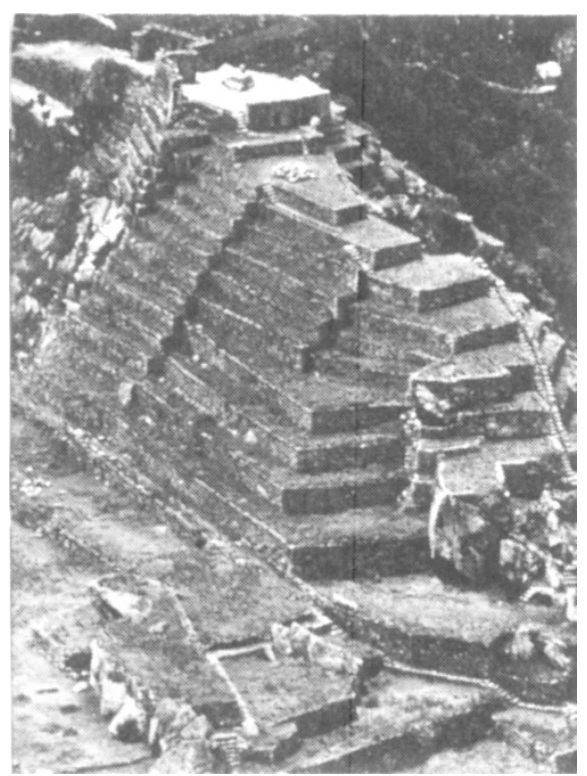

Inca terracing: old but efficient

Jorge Boggio, ITINTEC's director of technology. "Also, although we agree on the need to coordinate the country's scientific and technological research activities, I think it is wrong to give responsibility to a body whose members have had little experience of technological development.

Related views are expressed at the National Planning Institute, which has had a strong influence on carving out Peru's highly nationalistic industrial policy in recent years. "I feel that our country needs a very clear and longterm plan for science and technology, but it must be built on the long-term objectives of socio-economic planning," says the director of the institute's office of research and planning, Dr Fernando Gonzales Vigil. "We need to determine broad priorities first, and then inside these priorities to put an emphasis on specific areas of knowledge, rather than the other way round."

Much will depend on the attitude of the new Minister for Industry, Admiral Jorge Du Bois Gervase, a former head of the industrial service of Peru's navy and therefore, it is claimed. well aware of the problems of relating research to operational nceds.

Another factor will be the effects of the austerity measures that the government has been forced to take to avoid defaulting on its loans from the International Monetarv Fund. Although a pronosal to eliminate industrv's reauired contribution to ITINTEC has been successfully headed off, for example. the institute remains vulnerable.

But whatever the outcome, many feel that the policy finally adopted is likely to be one that increases support for the private sector, and weakens the role of state planners. "This would be the more logical outcome, taking into account the various national and foreign interests," says $\mathrm{Dr}$ Vigil.

\section{Andean Pact propose research tax on 1st world}

Already bidding for a place on the agenda of next year's UNCSTD meeting in Vienna is a proposal that has been put forward jointly by a group of Latin American countries and the Economic Commission for Latin America (ECLA) to establish a new fund for supporting technological development ventures in the Third World.

The countries concerned-Bolivia, Colombia, Ecuador, Peru and Venezuela-are members of the Andean Pact, an economic federation formed in 1969 to harmonise and coordinate the economic and technological policies of its constituent states.

From the beginning, the Andean Pact countries have expressed, mainly through the reports and studies of its secretariat's technical group, the Junta del Acuerdo de Cartagena, fierce criticism of the way that existing technology transfer and patent licensing policies have increased the dependency of the developing on the developed world.

The proposed fund is intended to strengthen the indigenous research and development capacities of developing countries. Contributions would be based on the size of the balance of trade on manufactured goods between rich and poor countries, with the general assumption that the greater the imbalance, the greater will be the technological gap.

Details of the proposals are now being revised in the light of comments made when the idea was discussed at the UNCSTD regional meeting for Latin America in Panama in August. Although doubts were raised by some of the countries present-mostly those claiming to be at an "intermediate" stage of development-others gave it enthusiastic support.

The Pact's position on technology, spelt out in a joint Decision 84 signed in June 1974, is based on the premise that if a country is to have control of its own development programmes. it is not enough merely to control the investment of capital (for example by regulating the financial activities of multinational companies). Equally important is control over the development and use of technology.

"It is easy to show, for example by looking at the way that the patent system has been used, that unless you have people who can control the 